\title{
Measures, Distribution and Decomposition of Poverty: An Empirical Analysis in Nepal
}

\author{
Pravat Uprety
}

Submitted: 24 May 2020; Accepted: 19 October 2020

Published online: 18 December 2020

DOI: https://doi.org// 0.3 | 26/njs.v4i0.33447

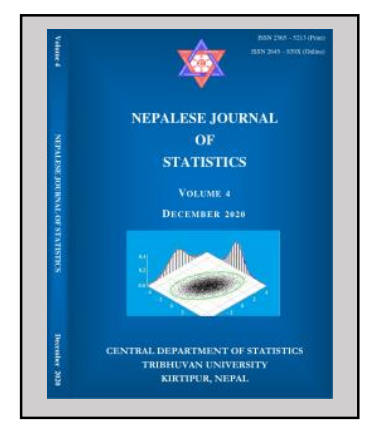

\section{ABSTRACT}

Background: Poverty has been in existence for many years and continues to exist in a large number of countries. Poverty is "pronounced in wellbeing" where wellbeing (and poverty) in broader term, focuses on the capability of the individual to function in society and poor people often lack key capabilities, they may have not adequate income, education, or be in poor health or feel powerless or lack of political freedoms. In Nepal, despite the decreasing trend in poverty incidence, still the current prevalence is very high with the comparison of other countries.

Objective: To identify, compare and decomposition of different poverty measures by rural urban area and ecological belt in Nepal.

Materials and Methods: Data set of Nepal Living Standard Survey (NLSS) conducted by Central Bureau of Statistics in $201 \mathrm{I}$ consisting of various variables related to food, non-food consumption, income, demographic, socioeconomics, etc., have been used for analysis. In order to measure the poverty, different measures such as head count ratio, poverty gap, poverty severity, Watts index and Sen-Shorrocks-Thon index were used. The comparisons of different poverty measures across different variables were attempted including use of appropriate poverty curves. The decomposition of poverty indices by consumption components using the Shapley value along with Lump-Sum Targeting approach has been applied.

Results: Average per capita consumption is 34186.5 , the head count index, poverty gap and poverty severity of Nepal are $0.2518,0.0545$ and 0.0182 , respectively. The poverty measures of rural area are higher than the urban area, and the incidence of poverty is highest in mountain ecological belt. Food and non-food component allows to $46.39 \% \& 28.42 \%$ of the total population to be non-poor of headcount index, $60.19 \% \& 34.34 \%$ for poverty gap index and $59.96 \% \& 38.20 \%$ for poverty severity, respectively.

Conclusion: For both within and overall population, rural area has the higher impact than urban area and each measure of poverty in mountain is significantly higher than hill and terai. To reduce within group headcount index and poverty gap, policymakers should give more focus to rural area and mountain region.

Keywords: FGT index, Sen-Shorrocks-Thon, Shapley decomposition, Watts index, 
Address correspondence to the author: Central Department of Statistics, Tribhuvan University, Kirtipur, Kathmandu, Nepal. E-mail: pravatup@gmail.com

\section{INTRODUCTION}

Poverty has been in existence for many years and continues to exist in a large number of countries. In 2015, United Nations General Assembly set the Sustainable Development Goals (SDGs) and intended to be achieved by 2030. The first goal of SDGs is to end poverty in all its forms everywhere and the second, third and four goals are zero hunger, good health and wellbeing and quality education respectively (UNDP, 20I5) are also directly related with the first goal. The other goals are also directly or indirectly related with the first goal of the SDG. To identify the status and achievement of poverty level any nation should require frequent measure of the poverty. Initially, economic development was thought of as economic growth, but in recent years it has increasingly come to be thought of as poverty reduction (Deaton, 2006). Therefore, targeting of poverty reduction is still remaining as an important issue in many countries especially least developed countries like Nepal.

According to Ravallion (1992), "The most important reason for measuring poverty is probably need for a single number for some place and data, rather to make a poverty comparison". So, it is clear that poverty measures can be used to compare the poverty by countries, by region, by geography, by socio economic variables, by time period, by policy (with and without), etc even within the country. In Nepal, poverty has been in declining trend. In 2011, 25.16\% of total population is below the poverty line and which was $41.8 \%$ in 1996 and $30.9 \%$ in 2003 (CBS, 20I la). Despite the significant decline in poverty, the incidence of poverty in Nepal is still high. Spatial variation of any nation or study area is one major dimension of the poverty analysis. Nepal is also spatially diversified country and it is divided into three geographical regions (ecological belt): terai (flat area), hill (mid range) and mountain. According to population census (20I I), the population distribution in mountain, hill and terai are $6.7 \%, 43.0 \%$ and $50.3 \%$ respectively. Due to lack of transport and coverage of snow in most of the area, not having fertile land, the price of food and non-food commodities is highest in mountain. Likewise rural and urban poverty is another dimension of poverty analysis. In Nepal, most of the people are residing in the rural area and dependent on agriculture. The rural and urban areas consist of $82.93 \%$ and $17.07 \%$ respectively of the total population (CBS, 20I lb).

In Nepal, the income, consumption, wellbeing and poverty vary according to rural urban area, geography and time. Various households' surveys have been conducting regularly in Nepal such as living standard survey, labor force survey, multiple indicator cluster survey, and demographic health survey. Among all, living standard survey is used to develop the absolute poverty line and in other surveys the various indicators of poverty, health, SDG are computed and presented by relative 
poverty. Nepal is the least developed country; the main focus of government is always reduction of poverty and making more wellbeing people. Since Nepal has been making the different plan and strategy to reduce the poverty incidence from first five year plan so that in Nepal, to make the poverty reduction strategy in coming days and also to evaluate the impact and effectiveness of past poverty reduction strategy, it is necessary to measure the poverty frequently. Likewise the access to education and health centers also varies according to poverty within each geographical region (Uprety, 2019). In order to reduce the poverty, policy maker should require the knowledge about the status of the poverty their distribution across the different subgroups and areas. It is also necessary to identity which area contributes more to the overall poverty and which area to be targeted to reduce overall poverty. Targeting of poverty remains an important issue in many countries. Identification of poverty indices is not only the major concern of the policy makers. It is also important to identity the distribution and decomposition of overall poverty and inequality into different subgroups. In Nepal, It is also fruitful to policy makers to study how the poverty distributed over the different subgroups such as geographical region, rural urban area etc. and their contribution to the overall poverty.

Mainly in developing countries consumptions is taken to measure the poverty. It is frequently argued that consumption is better suited than income as an indicator of living standards; one reason is that consumption is believed to vary more smoothly than income, both within a year and across the life cycle. Income is notoriously subject to seasonal variability, particularly in developing countries, whereas consumptions tend to be less variable. Likewise, it is also held to more readily observed, recalled and measured than income and less suffered than underreporting problem (Duclos \& Araar, 2006). On the other hand in least developed countries generally absolute poverty measure is used. An absolute poverty line is fixed in terms of the standards indicators being used and fixed over the entire domain of the poverty comparison (Ravallian, 1992). Absolute poverty lines are by far the most commonly used approach for identifying the poor over time and space and are universally used in low and middle-income countries. They allow transparent comparisons where the changes in measured poverty can be attributed purely to changes in the distribution rather than to a moving poverty cutoff (Foster, Seth, Lokshin, \& Sajaia, 2013). Haughton and Khandker (2010) argued that an absolute poverty line is essential if one is trying to judge the effect of antipoverty policies over time or to estimate the effect of antipoverty policies over time or to estimate the impact of a project related to poverty.

There are various poverty measures; the first distribution sensitive poverty measure proposed by Watts in 1968 was The Watts index. In 1976 Sen proposed an index termed as Sen Index by combining the number of poor, the depth of poverty and the distribution of poverty and later it was modified by others by taking the product of headcount index, the poverty gap index and Gini coefficient of poverty gap ratio and which is termed as The Sen-Shorrocks-Thon (SST) Index (Haughton \& Khandker, 2010). Haughton and Khandker (2010) also argued that among various poverty measures, the widely used and easy to compute is headcount index. It measures the proportion of the population that is poor. Likewise, another poverty measure technique is poverty 
gap index and it measures the extent to which individuals fall below the poverty line (the poverty gaps) as a proportion of the poverty line and next index named as the squared poverty gap index (also termed as poverty severity index) averages the squares of the poverty gaps relative to the poverty line. Foster, Greer and Thorbecks (1984) proposed one poverty measure popularly termed as FGT index and which (i) is additively decomposable with population-share weights, (ii) satisfies the basic properties proposed by Sen, and (iii) is justified by a relative deprivation concept of poverty. By using this measure; headcount index, poverty gap and poverty severity index can be easily computed by putting the value of parameter.

This paper is planned aiming to identify the overall poverty incidence by different poverty measure techniques, to compare and decompose the poverty measures by rural urban area and geography and to identify the contribution of different area and sources on different poverty measures.

\section{MATERIALS AND METHODS Data and variables}

To carry out this study the data of Nepal Living Standard Survey (NLSS) conducted by Central Bureau of Statistics (CBS), Nepal in $201 \mathrm{I}$ was used. It was a national level survey representing the whole country including rural, urban area and three ecological belts; mountain, hill and terai. The survey had enumerated 5988 sample households from 499 primary sampling units (PSUs) and 14 strata from the cross section sample (CBS, 20I Ic). There were altogether 20 sections in questionnaire and all data were arranged in 45 data files. In one data file named poverty; there were the data on per capita annual consumption, food consumption, non-food consumption, and price indices for the different analytical domain, poverty status and poverty line for per capita consumption and food consumption. This data file was used for this study.

\section{Description of variables}

In order to measure the poverty, real per capita consumption was used. To convert the nominal into real, the nominal value was divided by the price index. To compare and decompose the poverty and inequality, two variables; rural urban area and ecological belt were used.To take the sampling weight, The bureau of statistics had made two weights household weight and individual weight and both were available in data file and in order to analyze by Distributive Analysis Stata Package(DASP), "household size" in size variable and "household weight" as sampling weight (pweight) were taken. In Nepal, poverty estimation follows the Cost of Basic Needs (CBN) approach that is the poverty line can be defined as the expenditure value (in local currency) required by an individual to fulfill his/her basic needs in terms of both food and non-food items (CBS, 20I la). According to this method the poverty line for Nepal is Rs. I926I.I8 (CBS, 20I la). 


\section{Used indicators and analysis plan}

In order to analyze the poverty, five poverty measures (headcount index, poverty gap, poverty severity, Watts index and Sen-Shorrocks-Thon) were used. To obtain the poverty measure, the absolute poverty line (Rs. 19261.18) was used. Each poverty measure was compared by rural and urban area and ecological belt. To present the poverty incidence in graph, poverty curve was used. To test the significant difference between rural and urban, $t$-test was used. To test across the ecological region three combinations of two groups were made and $t$-test was used. To decompose the poverty, headcount and poverty gap and poverty severity were taken. The absolute and relative contributions of each group on overall poverty were analyzed. The marginal impacts of one unit change in consumption on within as well as overall were also computed and for this Lump-Sum Targeting technique was used. To decompose the consumption into its component Shapley approach was used. To compute the result STATA 16.0 along with DASP were used.

\section{Poverty measures}

To measure and compare the poverty, five poverty measures are used and all measures satisfy the six properties namely: symmetry, population invariance, focus, scale invariance, monotonicity, and transfer. To measure the poverty, the FGT index proposed by Foster, Greer, and Thorbecke (1984), was used, and it is written as $\mathrm{P}_{\alpha}=\frac{1}{N} \sum_{i=1}^{N}\left(\frac{g i}{z}\right)^{\alpha}$. When $\alpha=0$, FGT is simply the head count index, when $\alpha=\mathrm{I}$ the index gives the poverty gap, and when $\alpha=2$, it becomes the poverty severity index (Haughton \& Khandker, 2010).

Headcount Ratio $\left(P_{0}\right)(F G T$ index with $\alpha=0)$ : It is a crude measure of poverty that simply counts the number of people whose incomes are below the poverty line $\mathrm{z}$ and divides that number by the total number of people in the society.

Poverty Gap Measure $\left(P_{I}\right)(F G T$ index with $\alpha=I)$ : The second basic poverty measure is the poverty gap measure which is also widely used. The poverty gap measure (PG) is the average normalized shortfall with respect to the poverty line across the poor. The poverty gap measure lies between zero and one. Zero is obtained when there are no poor in the society. A value of one is obtained when everyone in the society is poor and has zero income (Foster, Seth, Lokshin, \& Sajaia, 2013).

Poverty Severity $\left(P_{2}\right)(F G T$ index with $\alpha=2)$ : It is squared poverty gap index and it is simply a weighted sum of poverty gaps. In poverty severity, the weights are the proportionate poverty gaps themselves and by squaring the poverty gap index, the measure implicitly puts more weight on observations that fall well below the poverty line (Haughton \& Khandker, 2010).

The Watts Index: This index was proposed by Watts in 1968, and it is the average difference between the logarithm of the poverty line and the logarithm of incomes/consumption. For 
income/consumption distribution $\mathrm{x}$ with population size $\mathrm{N}$ and poverty line $\mathrm{z}$, the Watts index can be written as:

$\mathrm{P}_{\mathrm{w}}(\mathrm{x} ; \mathrm{z})=\frac{1}{N} \sum_{i=1}^{q}\left(\ln z-\ln x_{i}\right)=\frac{1}{N} \sum_{i=1}^{q} \ln \left(\frac{z}{x_{i}}\right)$

where the $\mathrm{N}$ individuals in the population are indexed in ascending order of income (or consumption) and the sum is taken over the $q$ individuals whose income (or consumption) $x_{i}$ falls below the poverty line $z$. The lowest value, the Watts index can take is zero, which is obtained when no one is poor in the society. However, unlike the headcount ratio and the poverty gap measure, the Watts index has no maximum value (Haughton \& Khandker, 2010; Foster, Seth, Lokshin, \& Sajaia, 2013).

The Sen-Shorrocks-Thon (SST) Index: This poverty index was originally formulated in terms of a basic poverty measure and an inequality measure. The poverty gap measure is the basic poverty measure used for constructing the SST, and the Gini coefficient is the inequality measure. It is defined as:

$$
\mathrm{P}_{\text {sst }}=\mathrm{P}_{0} \mathrm{P}_{1}\left(\mathrm{I}+\hat{G}^{p}\right)
$$

which is the product of the headcount index, the poverty gap index (applied to poor only) and a term with the Gini coefficient of the poverty gap ratios for the whole population.

\section{Decomposition of poverty indices by group}

Araar and Duclos (2013) mentioned that the poverty index can be decomposed into population subgroups. If population consists of $G$ mutually exclusive subgroups, this decomposition takes the form as follows.

$$
\hat{P}(z ; \alpha)=\sum_{g=1}^{G} \hat{\phi}(g) \hat{P}(z ; \alpha ; g)
$$

where $G$ is the number of population subgroups. The estimated FGT index of subgroup g: $\hat{P}(z ; \alpha ; g)$ '; The estimated population share of subgroup $g: \hat{\phi}(g)$; The estimated absolute contribution of subgroup g to total poverty $\hat{\varphi}(g) \hat{P}(z ; \alpha ; g)$; The estimated relative contribution of subgroups g to total poverty $(\hat{\varphi}(g) \hat{P}(z ; \alpha ; g)) / \hat{P}(z ; \alpha)$.

\section{Decomposition by income/consumption components using the Shapley value}

Araar and Duclos (2013) also mentioned that it can be decomposed the FGT poverty index into a sum of the contributions generated by separate income components. Total alleviation is maximal when all individuals have an income greater than or equal to the poverty line. A negative sign on a decomposition term indicates that an income component reduces poverty. Assume that there exists $\mathrm{K}$ income sources and that $s_{k}$ denotes income source $k$. The FGT index is defined as: 


$$
\hat{P}\left(z ; \alpha ; y=\sum_{k=1}^{K} s_{k}\right)=\frac{\sum_{i=1}^{n} w_{i}(1-y / z)^{\alpha}}{\sum_{i=1}^{n} w_{i}}
$$

where $w_{i}$ is the weight assigned to individual $i$ and $n$ is the sample size. It estimates the share in total income of each income source $K$, the absolute contribution of each source $K$ to the value of $(\hat{P}-I)$ and the relative contribution of each source $K$ to the value of $(\hat{P}-I)$.

\section{Poverty and targeting by population groups (Lump-Sum Targeting)}

The Lump-Sum Targeting (LST) is the per capita dollar impact of a marginal addition of a constant amount of income to everyone within a group $K$ on the FGT poverty index $P(k, z ; \alpha)$ is as follows:

$$
\begin{array}{rlr}
\text { LST } & =-\alpha P(k, z ; \alpha-I) & \text { if } \alpha \geq I \\
& =-f(k, z) & \text { if } \alpha=0
\end{array}
$$

where $z$ is the poverty line, $k$ is the population subgroup for which we wish to assess the impact of the income change, and $f(k, z)$ is the density function of the group $k$ at level of income $z$. It estimates the impact of marginal change in income of the group on poverty of the group and that of the population (Araar \& Duclos, 2013).

\section{RESULTS}

The average per capita consumption, food consumption and non-food consumption per year are $34186.5,19284.7$ and 14901 .8 respectively. The average per capita food consumption is higher than the average per capita non-food expenditure (Table I).

Table I. Summary statistics of per capita consumption, food consumption and non-food consumption.

\begin{tabular}{lll}
\hline Variable & Mean & Standard Deviation \\
\hline Per capita consumption & 34186.5 & 25328.8 \\
Per capita food consumption & 19284.7 & 10457.1 \\
Per capita non-food consumption & 14901.8 & 18984.7 \\
\hline
\end{tabular}

The density curves (Figure I) of per capita consumption, food consumption and non-food consumption indicate that all are positively skewed that means all are concentrated towards the left side. It is obvious that in developing countries the household's income as well as consumption are low and right skewed can be seen. Among the distribution of three consumption types it seems that the non-food consumption is more concentrated towards the left side. 


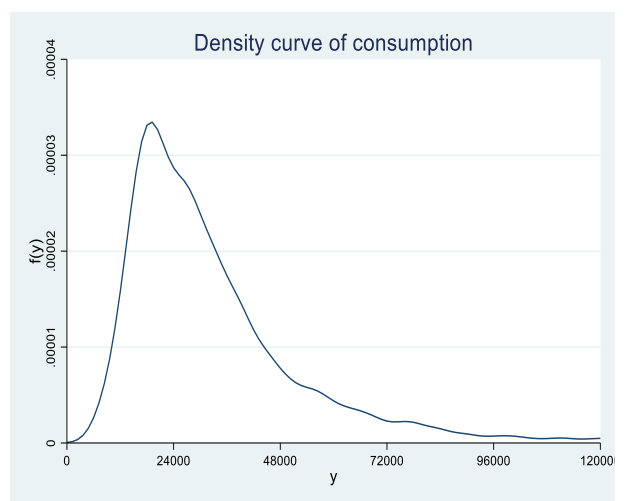

Fig. I (a). Density function of consumption.

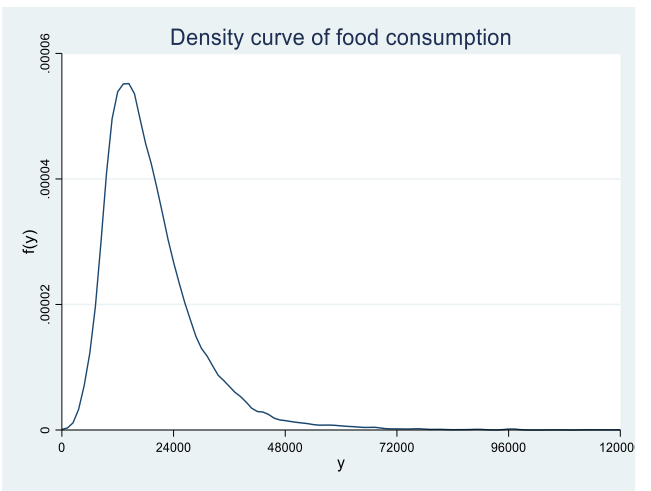

Fig. I (b). Density function of food consumption.

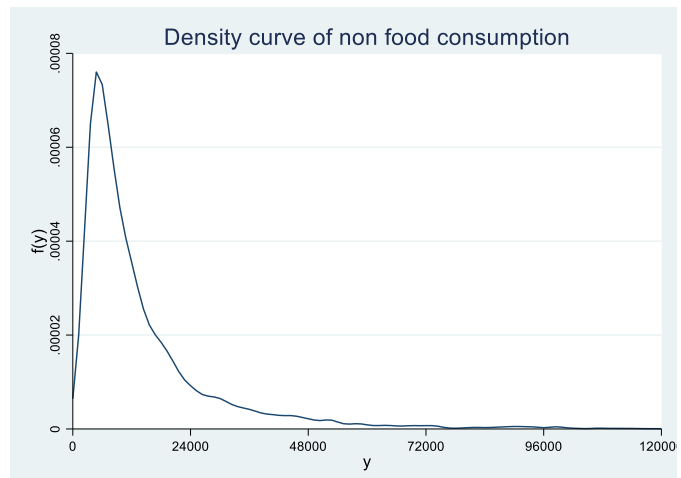

Fig. I (c). Density function of non-food consumption.

Table 2 shows that the average per capita consumption of urban area (44432) is higher than rural area (3178I) by 12650 and the difference is also significant. Likewise, across the ecological belt, the average per capita consumption of hill (352II) is highest and that of mountain (263/2) is lowest. The average per capita consumption of mountain is significantly different from the hill and terai. The average per capita consumptions of hill and terai seem almost similar.

\section{Analysis of poverty measures}

The overall headcount index, poverty gap and poverty severity are $0.2518,0.0545$ and 0.018253 respectively. By using the $50 \%$ of mean from the poverty line the head count index, poverty gap and severity poverty are 0.17 I387, 0.03444 and 0.01 I 225 respectively. Each FGT Index with absolute poverty measure is higher than the corresponding relative poverty measure. Likewise, the Watts index and Sen, Shorrocks and Thon index are 0.0679 and 0.1009 respectively (Table 3). 
Table 2. Comparison of per capita consumption by rural urban area and ecological region.

\begin{tabular}{llll}
\hline Rural/Urban area & Mean & t-value & P-value \\
\hline Urban & 44432 & 57.4 & $<0.00 I$ \\
Rural & $3178 \mathrm{I}$ & 91.8 & $<0.00 \mathrm{I}$ \\
\hline Ecological region & & & \\
\hline Mountain & 26312 & 33.87 & $<0.00 \mathrm{I}$ \\
Hill & $3521 \mathrm{I}$ & 78.50 & $<0.00 \mathrm{I}$ \\
Terai & 34396 & 68.79 & $<0.001$ \\
\hline Difference between & Difference & t-value & $\mathrm{P}$-value \\
\hline Urban and Rural & -1265 & -14.9 & $<0.001$ \\
Mountain and Hill & 8899 & 9.92 & $<0.001$ \\
Mountain and Terai & 8084 & 8.75 & $<0.001$ \\
Hill and Terai & -815 & -1.21 & 0.225 \\
\hline
\end{tabular}

Table 3. FGT indices when $\alpha=0, \mathrm{I}$, and 2 .

\begin{tabular}{llc}
\hline Poverty Type & Absolute Poverty & Relative Poverty (50\% of mean) \\
\hline FGT Index & & 0.171387 \\
Headcount Index $(\alpha=0)$ & 0.251839 & 0.034444 \\
Poverty Gap $(\alpha=I)$ & $0.05457 I$ & 0.011225 \\
Poverty Severity $(\alpha=2)$ & 0.018253 & \\
Watts Index & 0.067933 & \\
Sen, Shorrocks and Thon & 0.100999 & \\
index & & \\
\hline
\end{tabular}

\section{Comparing poverty by rural urban area and ecological belt}

The poverty curve (Figure 2(a)) of the headcount index in rural area is higher than urban in almost all range of poverty line. Likewise, the poverty gap and poverty severity of rural area is higher than the urban area at any poverty line. It can be seen that for these two measures the difference in rural and urban increases as poverty line increases (Figure 2(b) and 2(c)).

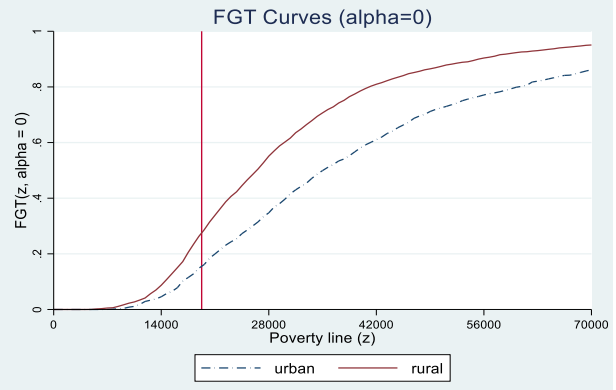

Fig. 2 (a). Poverty curve $(\alpha=0)$ of rural and urban area.

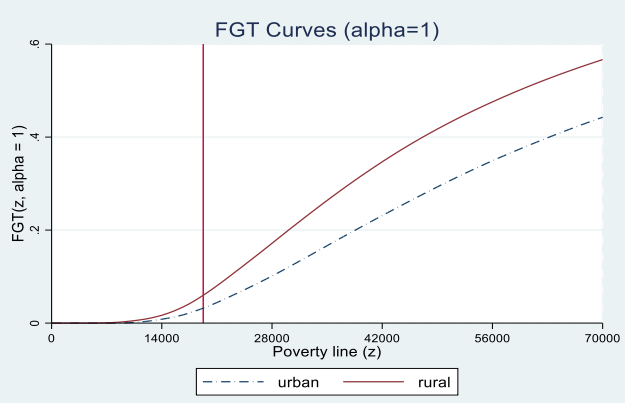

Fig. 2 (b). Poverty curve $(\alpha=1)$ by rural and area. 
area.

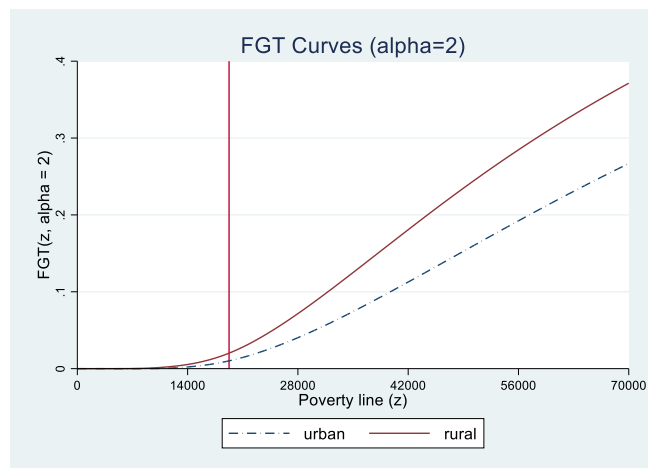

Fig. 2 (c). Poverty curve $(\alpha=2)$ by rural and urban region.

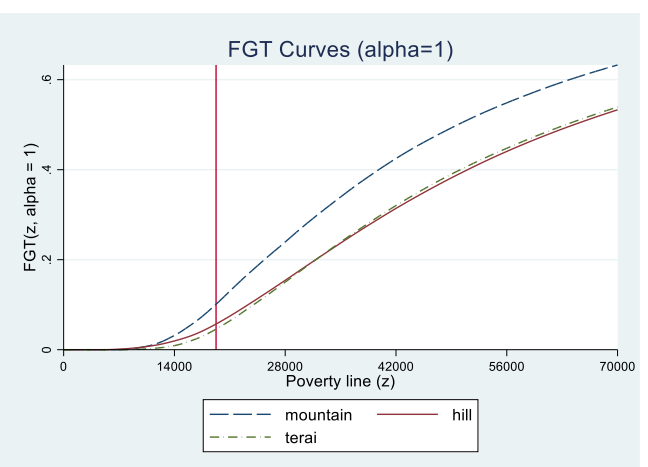

Fig. 2 (e). Poverty curve $(\alpha=1)$ by ecological region. and urban area.

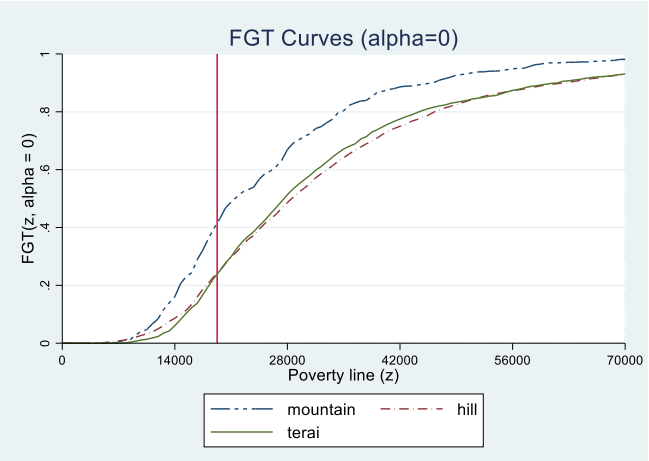

Fig. 2 (d). Poverty curve $(\alpha=0)$ by ecological region.

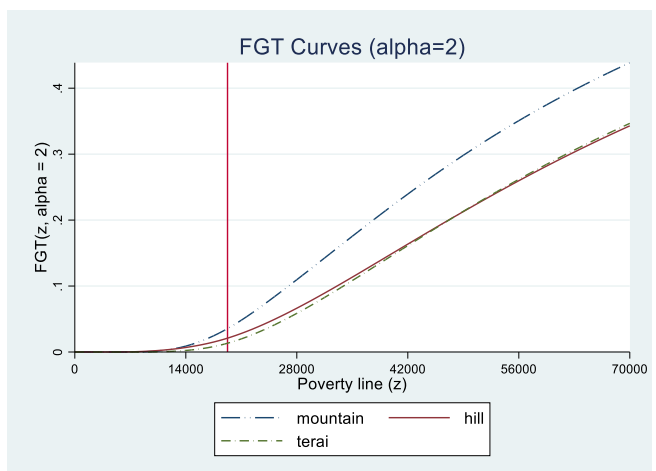

Fig. 2 (f). Poverty curve $(\alpha=2)$ by ecological region.

Figures 2(d), 2(e) and 2(f)) indicate that the poverty curve of all three poverty measures in mountain is highest than hill and terai. The poverty curve of hill and terai seems almost similar at any poverty line. Table 4 indicates that each poverty measure of rural area is higher than that of the urban area and the difference is also significant. The headcount index of mountain is highest and hill and terai are almost similar. Likewise, the poverty gap of mountain is also highest and which is followed by hill and terai and same pattern can also be seen in poverty severity index. All FGT indices of mountain are significantly different from hill and terai. The headcount index between hill and terai are not significantly different but the poverty gap and poverty severity between hill and terai are significantly different. Table 5 shows that the absolute contributions of rural and urban area are 0.22239 and 0.02946 to the total head count index. The relative contribution of rural area $(88.30 \%)$ is higher than its population shares $(80.98 \%)$ so that policy makers should give more focus on rural area to reduce the headcount poverty incidence. 
Table 4. Comparison of FGT index by rural and urban area and ecological region.

\begin{tabular}{|c|c|c|c|c|c|}
\hline \multirow[b]{4}{*}{ Group } & \multicolumn{3}{|c|}{ FGT Index } & \multirow[t]{4}{*}{ Watts Index } & \multirow{4}{*}{$\begin{array}{l}\text { Sen Shorrocks } \\
\text { and Thon index }\end{array}$} \\
\hline & \multirow{3}{*}{$\begin{array}{l}(\alpha=0) \\
\text { Headcount } \\
\text { index }\end{array}$} & \multirow{3}{*}{$\begin{array}{l}(\alpha=1) \\
\text { Poverty gap }\end{array}$} & \multirow{3}{*}{$\begin{array}{l}(\alpha=2) \\
\text { Severity } \\
\text { poverty }\end{array}$} & & \\
\hline & & & & & \\
\hline & & & & & \\
\hline \multicolumn{6}{|l|}{$\begin{array}{l}\text { Rural/Urban } \\
\text { area }\end{array}$} \\
\hline Urban & 0.15488 & 0.03211 & 0.01014 & 0.0391819 & 0.06124 \\
\hline Rural & 0.27461 & 0.05985 & 0.02016 & 0.0746846 & 0.10996 \\
\hline \multicolumn{6}{|l|}{$\begin{array}{l}\text { Ecological } \\
\text { region }\end{array}$} \\
\hline Mountain & $0.4 I 1082$ & 0.100893 & 0.035453 & 0.12645 & 0.17579 \\
\hline Hill & 0.240836 & 0.057013 & 0.020990 & 0.07317 & 0.10595 \\
\hline Terai & 0.238796 & 0.045658 & 0.013283 & 0.05470 & 0.08477 \\
\hline \multirow[t]{2}{*}{ Population } & 0.251839 & $0.05457 \mid$ & 0.018253 & & \\
\hline & \multicolumn{5}{|c|}{ t-value and $p$-value } \\
\hline Rural and & 9.06380 & 7.76073 & 6.39829 & 7.5224 & 7.61032 \\
\hline Urban & $<0.001$ & $<0.001$ & $<0.001$ & $<0.001$ & $<0.001$ \\
\hline $\begin{array}{l}\text { Mountain and } \\
\text { Hill }\end{array}$ & $\begin{array}{l}-.48634 \\
(<0.001)\end{array}$ & $\begin{array}{l}-4.2163 \\
(<0.001)\end{array}$ & $\begin{array}{l}-2.9160 \\
(0.004)\end{array}$ & $\begin{array}{l}-3.77018 \\
(<0.001)\end{array}$ & $\begin{array}{l}-4.23445 \\
(<0.001)\end{array}$ \\
\hline $\begin{array}{l}\text { Mountain and } \\
\text { Terai }\end{array}$ & $\begin{array}{l}-5.4816 \\
(<0.001)\end{array}$ & $\begin{array}{c}-5.3714 \\
(<0.001)\end{array}$ & $\begin{array}{l}-4.6159 \\
(<0.001)\end{array}$ & $\begin{array}{l}-5.18663 \\
(<0.001)\end{array}$ & $\begin{array}{l}-5.60529 \\
(<0.001)\end{array}$ \\
\hline Terai and Hill & $\begin{array}{l}-0.14 \mid \mathrm{I} \\
(0.887)\end{array}$ & $\begin{array}{l}-2.7790 \\
(0.005)\end{array}$ & $\begin{array}{c}-3.9807 \\
(<0.001)\end{array}$ & $\begin{array}{l}-3.30754 \\
(<0.001)\end{array}$ & $\begin{array}{c}-2.93599 \\
(0.003)\end{array}$ \\
\hline
\end{tabular}

Table 5. Decomposition of the FGT index $(\alpha=0)$ and targeting poverty by rural urban area/ecological belt.

\begin{tabular}{llllllc}
\hline Group & $\begin{array}{l}\text { FGT Index } \\
(\alpha=0)\end{array}$ & $\begin{array}{l}\text { Population } \\
\text { Share }\end{array}$ & $\begin{array}{l}\text { Absolute } \\
\text { Contribution }\end{array}$ & $\begin{array}{l}\text { Relative } \\
\text { Contribution }\end{array}$ & $\begin{array}{l}\text { Impact on } \\
\text { Group }\end{array}$ & $\begin{array}{l}\text { Impact on } \\
\text { Population }\end{array}$ \\
\hline Rural/Urban area & & & & & & \\
\hline Urban & 0.15488 & 0.19018 & 0.02946 & 0.11696 & $-2.1 \mathrm{E}-05$ & $-4 \mathrm{E}-06$ \\
Rural & $0.2746 \mathrm{I}$ & 0.80983 & 0.22239 & 0.88304 & $-3.6 \mathrm{E}-05$ & $-2.9 \mathrm{E}-05$ \\
\hline Ecological region & & & & & & \\
\hline Mountain & 0.41108 & 0.07047 & 0.02897 & 0.11503 & -0.00004 & $-3 \mathrm{E}-06$ \\
Hill & 0.24084 & 0.44219 & 0.10650 & 0.42287 & $-3.1 \mathrm{E}-05$ & $-1.4 \mathrm{E}-05$ \\
Terai & 0.23879 & 0.48733 & 0.11637 & 0.46209 & $-3.4 \mathrm{E}-05$ & $-1.7 \mathrm{E}-05$ \\
\hline Population & 0.25184 & 1.00000 & 0.25184 & 1.00000 & $-3.3 \mathrm{E}-05$ & $-3.3 \mathrm{E}-05$ \\
\hline
\end{tabular}


In rural area, one unit increase on per capita consumption reduces the headcount index by 0.000036 point within and by 0.000029 in overall headcount index and both are higher than the urban area. The absolute contribution of mountain, hill and terai are 0.02897, 0.10650 and 0.1 I637 respectively. The relative contribution of mountain is higher than its population share but for hill and terai the relative contribution is less than the population share. To reduce the head count index within group it is better to give more target to mountain because it has the highest impact on group $(0.0000428)$ and to reduce the headcount index to overall population it is better to give the target on terai region since it has the highest marginal impact on total population.

Table 6. Decomposition of the FGT index $(\alpha=1)$ and targeting poverty by rural urban area/ecological belt.

\begin{tabular}{|c|c|c|c|c|c|c|}
\hline \multirow[b]{2}{*}{ Group } & \multirow[b]{2}{*}{$\begin{array}{l}\text { FGT Index } \\
(\text { alpha =I) }\end{array}$} & \multirow[b]{2}{*}{ Population } & \multirow[b]{2}{*}{$\begin{array}{l}\text { Absolute } \\
\text { Contribution }\end{array}$} & \multicolumn{3}{|c|}{ Impact } \\
\hline & & & & $\begin{array}{l}\text { Relative } \\
\text { Contribution }\end{array}$ & $\begin{array}{l}\text { on } \\
\text { Group }\end{array}$ & $\begin{array}{l}\text { Impact on } \\
\text { Population }\end{array}$ \\
\hline \multicolumn{7}{|c|}{ Rural/Urban area } \\
\hline Urban & 0.03211 & 0.19018 & 0.00611 & 0.11188 & $-8 \mathrm{E}-06$ & $-1.5 \mathrm{E}-06$ \\
\hline Rural & 0.05985 & 0.80983 & 0.04847 & 0.88812 & $-1.4 \mathrm{E}-05$ & $-1.2 \mathrm{E}-05$ \\
\hline \multicolumn{7}{|c|}{ Ecological region } \\
\hline Mountain & 0.10089 & 0.07047 & $0.007 \mathrm{II}$ & 0.13029 & $-2.1 \mathrm{E}-05$ & $-1.5 \mathrm{E}-06$ \\
\hline Hill & 0.05701 & 0.44219 & 0.02521 & 0.46197 & $-1.3 \mathrm{E}-05$ & $-5.5 E-06$ \\
\hline Terai & 0.04566 & 0.48734 & 0.02225 & 0.40774 & $-1.2 \mathrm{E}-05$ & $-6 \mathrm{E}-06$ \\
\hline Population & 0.05457 & 1.00000 & 0.05457 & 1.00000 & $-1.3 \mathrm{E}-05$ & $-1.3 \mathrm{E}-05$ \\
\hline
\end{tabular}

Table 6 depicts the absolute contribution to the poverty gap of rural area $(0.04847)$ is higher than that of urban area $(0.006 \mathrm{II})$. The relative contribution to the poverty gap of rural area $(0.88812)$ is also higher than its population share $(0.80983)$. Similarly, one unit increase in consumption on rural area reduces the poverty gap by 0.0000143 within rural and 0.0000115 in population and both are higher than urban area. Therefore, focuses are to be given to rural area to reduce the poverty gap. Likewise, among the ecological belt, the absolute contribution of hill is highest. The relative contribution to the poverty gap of mountain $(0.13029)$ and hill $(0.46197)$ are higher than the respective population share. To see the marginal impact, one unit increase in per capita consumption decreases the head count poverty in mountain, hill and terai by 0.0000213 , 0.0000125 and 0.0000124 respectively. To reduce the poverty gap within group, mountain area should be more targeted because there is highest marginal impact within group and to reduce the overall poverty it is better to target terai because it has highest impact on population. Table 7 shows the absolute contribution, relative contribution, impact on group and population of rural urban area and ecological regions on poverty severity. The absolute contribution of rural area $(0.016326)$ is higher than the urban area and among the ecological regions, the hill has the highest $(0.00928)$ absolute contribution on poverty severity. 
Table 7. Decomposition of the FGT index $(\alpha=2)$ and targeting poverty by rural urban area/ecological belt.

\begin{tabular}{|c|c|c|c|c|c|c|}
\hline \multirow[b]{2}{*}{ Group } & \multirow[b]{2}{*}{$\begin{array}{l}\text { FGT Index } \\
\text { (alpha }=2 \text { ) }\end{array}$} & \multirow[b]{2}{*}{ Population } & \multirow[b]{2}{*}{$\begin{array}{l}\text { Absolute } \\
\text { Contribution }\end{array}$} & \multirow[b]{2}{*}{$\begin{array}{l}\text { Relative } \\
\text { Contribution }\end{array}$} & \multicolumn{2}{|l|}{ Impact } \\
\hline & & & & & $\begin{array}{l}\text { on } \\
\text { Group }\end{array}$ & $\begin{array}{l}\text { Impact on } \\
\text { Population }\end{array}$ \\
\hline \multicolumn{7}{|c|}{ Rural/Urban area } \\
\hline Urban & 0.010135 & 0.19018 & 0.001928 & 0.105598 & $-3.3 \mathrm{E}-06$ & $-6.3 \mathrm{E}-07$ \\
\hline Rural & 0.020160 & 0.80983 & 0.016326 & 0.894402 & $-6 \mathrm{E}-06$ & $-5 \mathrm{E}-06$ \\
\hline \multicolumn{7}{|c|}{ Ecological region } \\
\hline Mountain & 0.035453 & 0.07047 & 0.002498 & 0.136877 & $-1 \mathrm{E}-05$ & $-7.4 \mathrm{E}-07$ \\
\hline Hill & 0.020990 & 0.44219 & 0.009282 & 0.508491 & $-5.9 \mathrm{E}-06$ & $-2.6 \mathrm{E}-06$ \\
\hline Terai & 0.013283 & 0.48734 & 0.006473 & 0.354632 & $-4.7 \mathrm{E}-06$ & $-2.3 \mathrm{E}-06$ \\
\hline Population & 0.018253 & 1.00000 & 0.018253 & 1.000000 & $-5.7 E-06$ & $-5.7 \mathrm{E}-06$ \\
\hline
\end{tabular}

In total consumption, the share of food and non-food are $56.41 \%$ and $43.58 \%$ respectively. Food and non-food component allows to $46.39 \%$ and $28.42 \%$ of the total population to be nonpoor of headcount index. Likewise, this amount for poverty gap index for food and non-food index are $60.19 \%$ and $34.34 \%$ respectively, and for poverty severity, the amount is $59.96 \%$ and $38.20 \%$ respectively (Table 8 ).

Table 8. Decomposition of the FGT index by consumption components (using the Shapley value).

\begin{tabular}{|c|c|c|c|c|c|c|c|}
\hline \multirow[t]{3}{*}{ Source } & \multirow{2}{*}{$\begin{array}{l}\text { Consu } \\
\text { mption }\end{array}$} & \multicolumn{2}{|l|}{$\alpha=0$} & \multicolumn{2}{|l|}{$\alpha=I$} & \multicolumn{2}{|l|}{$\alpha=2$} \\
\hline & & Absolute & Relative & Absolute & Relative & Absolute & Relative \\
\hline & Share & Contrib.* & Contrib.* & Contrib.* & Contrib.* & Contrib.* & Contrib.* \\
\hline $\begin{array}{l}\text { Per capita } \\
\text { consumption } \\
\text { on food }\end{array}$ & $0.564 I$ & -0.46390 & 0.62005 & -.60196 & 0.6367 & -0.5996 & 0.6108 \\
\hline $\begin{array}{l}\text { Per capita } \\
\text { consumption } \\
\text { on non-food }\end{array}$ & 0.4358 & -0.28426 & 0.37994 & -0.34346 & 0.3632 & -0.3820 & 0.3892 \\
\hline Total & 1.0000 & $-0.748|6|$ & 1.00000 & -0.9454 & 1.0000 & -0.9817 & 1.0000 \\
\hline
\end{tabular}

\section{DISCUSSION}

The consumption is an indicator of living standards as well as achievement and fulfillment of basic needs. In Nepal, consumption, food consumption as well as non-food consumption are very low and indicate that large number of people are living with low living standards and facing the lack of basic needs. Despite the decreasing the poverty incidences, it is high with comparison of other countries. The all poverty measures are higher in rural area than the urban area. The poverty severity measure (extreme poverty) in rural area is almost two times higher than the urban area. The relative contribution of rural area is also higher than its population share for all 
FGT indices. The marginal impacts of one unit change in consumption on group as well as on population of rural area are higher than the urban area. From all perspectives, to reduce overall poverty as well as extreme poverty rural area should be more focused than urban.

Across the ecological region, the three FGT indices of mountain are highest. The relative contribution of mountain is also higher than its percentage share. The marginal impact on within is highest in mountain for all indices. It shows that one unit change in consumption decreases the poverty in mountain is relatively higher than hill and terai but to reduce overall poverty targeting terai is more effective. Hence, mountain region should be more focused to reduce the headcount index, poverty gap as well as poverty severity. In mountain, most of the areas are covered by snow and having little fertile area, both food and non-food items are relatively more expensive with the comparison of hill and terai so that there is more likelihood of less consumption and consequently increases the poverty incidence. To reduce the poverty incidence in mountain government or policy maker should give more priority to make the road and easy access to transportation and then it would reduce the price of commodity and consequently increases the consumption level and reduces poverty incidence. In rural area, most of the household are involved in agricultural area and the people are more secure in food consumption than urban area but they do not spend much more in non-food consumption like clothing item, education, fuels etc. so that there seems more poorer than urban area. To reduce the rural poverty, government or policy maker should make different income generated policy such as scientific agriculture to produce more farm production and small enterprises and access to market center. Similarly to reduce the rural poverty it is necessary to developed skilled man power and human capital. Consequently, the people of rural area can earn more and spend much more on consumption especially non-food items and reduces the rural poverty as well as overall poverty.

\section{CONCLUSION}

The poverty incidence in Nepal is still high. The per capita consumption and income are still low in Nepal. The per capita consumption is 34186.5 and the per capita food consumption is higher than the non-food consumption. The per capita consumption in urban is higher than rural area and across the ecological belt, lowest in mountain and highest in hill. The headcount index, poverty gap and poverty severity are $0.25184,0.05457$ and 0.018253 respectively. Each measure of poverty in rural area is significantly higher than the urban area. The relative contribution to the headcount index of rural area is higher than population share. One unit increase in consumption in rural area reduces the headcount index by 0.000036 point within and by 0.000029 overall. From the marginal impact analysis, to alleviate the poverty rural area should be more focused. To reduce the poverty gap, for both within and overall population, rural area has the higher impact than urban area so that rural area should be more targeted. Likewise, each measure of poverty in mountain is significantly higher than hill and terai. To reduce within group headcount index and poverty gap policy maker should give more focus to mountain and to reduce the overall incidence of poverty terai should be more focused. 


\section{CONFLICT OF INTEREST}

The author declared that there is no conflict of interest.

\section{ACKNOWLEDGEMENTS}

The author would like to extend gratitude to all supporters, reviewers and the secondary data provider Central Bureau of Statistics, Thapathali, Kathmandu.

\section{REFERENCES}

Araar, A., \& Duclos, J.Y. (20|3). Usual manual: DASP version 2.3.

Retrieved from http://dasp.ecn.ulaval.ca/modules/DASP_V2.3/DASP_MANUAL_V2.3.pdf

Central Bureau of Statistics (20I la). Poverty in Nepal 2010/20 I I. Kathmandu: CBS.

Central Bureau of Statistics (20 I lb). National population and housing census 20 I I (national Report). Kathmandu: CBS.

Central Bureau of Statistics (20I Ic). Nepal Living Standard Survey 20 10/20 I I. Statistical report, Volume I. Kathmandu: CBS.

Deaton, A. (2006). Measuring Poverty. Understanding Poverty. Oxford: Oxford University Press. Retrieved from http://www.princeton.edu/ deaton/downloads/Deaton_Measuring_Poverty.pdf

Duclos, J.Y., \& Araar, A. (2006). Poverty and equity: Measurement, policy, and estimation with DAD. New York: Springer.

Foster, J.E., Greer, J., \& Thorbecke, E. (1984). A class of decomposable poverty measures. Econometrica, 52, 761-766.

Foster, J., Seth, S., Lokshin, M., \& Sajaia, Z. (2013). A Unified Approach to Measuring Poverty and Inequality, Washington D.C.: The World Bank.

Haughton, J., \& Khandker, S.R. (2010). Hand book on poverty + inequality. New Delhi: Rawat Publication.

Ravallian, M. (1992). Poverty comparisons: A guide to concepts and methods, living standards measurement study. World Bank Working Paper, 88.

UNDP (2015). Sustainable development goals. Retrieved from: https:/www.undp.org/content/undp/en/home/sustainable-development-goals.html

Uprety, P. (2019). Linkages between time to reach education centers, health facility centers, poverty status and geography: A multivariate approach. Nepalese Journal of Statistics, 3, 6988.

doi: https://doi.org//0.3126/njs.v3i0.25579

Reference to this paper should be made as follows:

Uprety, P. (2020). Measures, distribution and decomposition of poverty: An empirical analysis in Nepal. Nep. J. Stat, 4, I-I6. 
